\title{
Seasonal Reproductive Biology and Artificial Propagation of Female African Catfish (Clarias gariepinus) After Hormonal Stimulation
}

\author{
Saadea A. M. Saadony; M. A. Eldanasoury; Badiaa A. Ali and Safaa M. Sharaf* \\ Animal Production \& Fish Resources Dept., Faculty of Agriculture, Suez Canal University, 41522 Ismailia. Egypt.
}

Received: $2 / 6 / 2014$

\begin{abstract}
The use of exogenous hormones to induce final oocyte maturation, ovulation, and spawning has become commonplace in the reproductive protocols for many species. In the present study, African catfish (Clarias gariepinus) were monthly collected from January to December 2011 for studying their monthly reproductive biology. Also, hormonal stimulation was done using ovaprim, human chorionic gonadotropin (hCG), and salmon gonadotropin releasing hormone analog (GnRHa). However, fish $(337.2$ - $718.0 \mathrm{~g})$ were divided into seven groups (each group contained four females and four males) and injected into the dorsal musculature by $0.4,0.5 \mathrm{ml} \mathrm{kg}{ }^{-1}$ Ovaprim, 1000 , $3000 \mathrm{IU} \mathrm{kg}^{-1} \mathrm{hCG}$, and $0.75,1 \mathrm{ml} \mathrm{kg}{ }^{-1} \mathrm{GnRHa}$. The control group was injected by $0.9 \%$ saline. At the dosage tested, gonado-somatic index (GSI), absolute fecundity, ovulation index, egg diameter, fertilization rate were significantly affected in all stimulated groups. It was found that the hormonal treatments are a useful method for commercial African catfish breeders to ensure the continuity of access larvae. However, the best reproductive performance was obtained at $0.5 \mathrm{ml} \mathrm{kg}^{-1}$ ovaprim, $3000 \mathrm{IU} \mathrm{kg}{ }^{-1} \mathrm{hCG}$, and $0.75 \mathrm{ml} \mathrm{kg}^{-1} \mathrm{GnRHa}$.
\end{abstract}

Keywords: African catfish, reproductive biology, artificial propagation, hormonal treatments.

\section{INTRODUCTION}

Reproduction in fish, as in other vertebrates, is under hormonal regulation by the hypothalamuspituitary-gonadal axis. Understanding of the seasonal patterns provides an important base line for the description of the fish biology and their role in aquatic ecosystems (Vazzoler, 1996). When direct inspection of gonadal maturation is not available, reproductive studies are frequently based on quantitative indices, as gonadosomatic index values (GSI) and condition factor $\left(\mathrm{K}_{\mathrm{f}}\right)$, which help to define reproductive cycles and possible variation in the physiological condition of species during the course of its lifespan (Kreiner et al., 2001 and Braga, 2005). The main factors involved in the control of reproduction are pituitary gonadotropins and gonadal steroids (Barannikova, et al., 2004). Some species do not reproduce in captivity due to environmental or culture conditions which may cause stress or may not provide the required conditions needs to complete the reproductive process (Zohar and, Mylonas 2001) and as a result there is a failure of the pituitary to release the maturational gonadotropin, luteinizing hormone (LH). Use of exogenous hormones is an effective way to induce maturation of eggs. Furthermore, in the most cultured fish, hormonal manipulations may be used as management tools to enhance and synchronized egg maturation, spermiation and facilitate hatching operations (Mylonas, et al., 2010). Also hormonal preparations applied in fish aquaculture allow improving artificial reproduction techniques both during and outside the spawning season (Cejko, et al., 2009).

African catfish, Clarias gariepinus, is a freshwater fish that has a wide distribution from in Africa and Europe because of its rapid growth, resistance to stress and feasible reproduction in captivity have made it a good candidate for aquaculture (Barnhoorn et al., 2004; Ali and Jauncey, 2005). African catfish is the principal clarid catfish in Africa (Teugels, 1984), where it is one

*Corresponding author: safaa_sharaf@agr.suez.edu.eg of the most abundant and widely distributed fish in River Nile, its tributaries and lakes and it has long been considered as one of the most suitable species for culture in Africa (El Bolok and Koura, 1960; DeKimpe and Micha, 1974). Moreover, Clarias species are widely cultivated under various systems (Huisman and Richter, 1987; Haylor, 1989). Although catfish aquaculture is one of the fastest growing activities in Africa, Europe, and America, this fish was neglected for many years and its aquaculture has not yet been performed commercially in Egypt. However, its production in Egypt reached about 48750 tones (about $4.79 \%$ of the total aquaculture production in 2012 (GAFRD, 2012).

Captive propagation of African catfish is essential to meet the growing demands for its fry. To this end, the aquaculture industry must find reliable and cost effective methods to its spawn. Captive spawning of broodstock is an integral component in the commercial production of finfish and significant investments are made in infrastructure to ensure crucial environmental cues can be properly replicated and manipulated. If the African catfish is to be widely used as a species of choice, the development of a reliable and simple method for fry production is needed. The development of a reliable methodology for spawning of African catfish without the use of hormone injections would greatly improve the prospects of aquaculture in Africa. Earlier work has shown that it is possible to produce African catfish fingerlings by subjecting the brood fish to a physical stress of reduced water depth and/or increased temperature (El Naggar et al., 2006). Also, this fish could be induced to spawn through a hormonal treatment. Therefore, the aim of this work is studying the monthly variations of ovaries maturation and plasma steroid hormones in female catfish. The effect of the hormonal treatments by ovaprim, human chorionic gonadotropin (hCG), and salmon gonadotropin releasing hormone analog (GnRHa) on the reproductive performance of African catfish was also determined.

Volume (2):21-31 


\section{MATERIALS AND METHODS}

\section{Experimental design:}

The present study was consisted of two experiments and it was carried out at the wet Lab., Department of Animal Production and Fish Resources, Faculty of Agriculture, Suez Canal University, Ismailia, Egypt. The first experiment was done to evaluate the monthly changes in reproductive performance of African catfish (C. gariepinus). However, fish $(337.20-718.00 \mathrm{~g})$ in body weight and $36.80-47.60 \mathrm{~cm}$ in length for female were monthly collected from the commercial catch of El-Cab region between Ismailia and Port Said from January to December 2011. Females were collected monthly and stocked in indoor 100-L plastic tanks (one for each group), which were covered by net to prevent fish jumping, as well as decreasing visual disturbance. All fish were exposed to normal photoperiod of $12 \mathrm{~L}$ : 12 D. The different morphometric measurements were done monthly for each fish at the laboratory.

\section{Artificial propagation experimental design:}

The second experiment was done to evaluate the effect of hormonal stimulation on the reproductive performance of African catfish. The experiment was carried out during the spawning season from July to August 2011 at Animal Production and Fish Resources Department, Faculty of Agriculture, Suez Canal University, Ismailia, Egypt. Both males and females were collected from the brood stock pond for spawning operation. Males were selected on the basis of pointed and reddish genital papilla, while females by a round and reddish papilla, softness of abdomen as described by (Sahoo et al., 2004) and uniform size of intra-ovarian oocytes. Fifty six sexually mature fish (28 males and 28 females) with an average body weight $(620.82 \pm 42.79 \mathrm{~g}$ for female and $552.89 \pm 38.74 \mathrm{~g}$ for males and average body length of $42 \pm 0.58 \mathrm{~cm}$ for both sexes were purchased from the commercial catch of El-Cab region and transferred to the wet laboratory and stocked in a concrete basin for $12 \mathrm{~h}$ for acclimatization to the laboratory conditions. All fish were maintained at a water temperature of $25 \pm 2^{\circ} \mathrm{C}$, exposed to normal photoperiod of $12 \mathrm{~L}: 12 \mathrm{D}$, and did not feed during the experimental period. Fish were randomly divided into seven groups, each group contained of eight fish (four females and four males) and were placed in indoor 100L plastic tanks (one for each group), which were covered by net to prevent jumping as well as decreasing visual disturbance. Males and females were separately, kept before injection individually body weight of males and female was recorded to study egg quality. At the end of the desired latency period of $12 \mathrm{~h}$ before stripping, individual weight of females were recorded. Females were individually stripped into dry and weighted in a Petri dish to record the stripped egg weight. The stripped females were killed and their ovaries were removed for determining the ovulation index. Sub-samples of $1 \mathrm{~g}$ eggs were weighed from the total stripped eggs of each female and the number of eggs was counted. Thus, the total number of eggs (spawning fecundity) was calculated for an individual female in each concentration. Four subsamples of each eggs were weighed and mixed with 4-5 drops of sperm suspension.

\section{Induced spawning hormones:}

The used hormones in the present study were ovaprim, which is a mixture of $20 \mu \mathrm{g} / \mathrm{ml}$ salmon gonadotropin-releasing hormone analogue (sGnRHa [DArg6-Pro9-NEt sGnRH]) with $10 \mathrm{mg} / \mathrm{ml}$ dopamine antagonist, Domperidone (Syndel laboratories Canada.), human chorionic gonadotropin (hCG) (PregnylOrganon, Brazil), and GnRH analogue (Buserelin acetate: Hoechst Veterinär GmbH; Unterschl- Eissheim b-München, Germany).

\section{Hormonal treatments:}

Fish were divided into seven groups (each group containing four females and four males). For induction of ovulation in July 2011, the hormonal treatments were used as follows:

\begin{tabular}{lc}
\hline \multicolumn{1}{c}{ Treated groups } & Hormone concentrations \\
\hline Control (Saline) & $0.9 \% \mathrm{NaCl}$ \\
Ovaprim & $0.4 \mathrm{ml} \mathrm{kg}^{-1}$ fish \\
Ovaprim & $0.5 \mathrm{ml} \mathrm{kg}^{-1}$ fish \\
hCG (Pregnyl) & $1000 \mathrm{IU} \mathrm{kg}^{-1}$ fish \\
hCG (Pregnyl) & $3000 \mathrm{IU} \mathrm{kg}^{-1}$ fish \\
GnRHa (Receptal) & $0.75 \mathrm{ml} \mathrm{kg}^{-1}$ fish \\
GnRHa (Receptal) & $1.0 \mathrm{ml} \mathrm{kg}^{-1}$ fish \\
\hline
\end{tabular}

Each group was injected at $9.00 \mathrm{pm}$ intramuscularly above the lateral line; just below the dorsal fin. The injected area was rubbed with a finger in order to distribute the hormone evenly throughout the muscle and to prevent a backflow of the hormone. After 12 hours latency period (the period between hormonal injection and ovulation), females were stripped and males sacrificed and dissected in order to remove the testes and use the milt. Eggs were stripped into dry plastic bowls, immediately weighed and one gram eggs were taken and carefully counted to obtain an estimate number of eggs produced per female. Eggs remained fertilized with the milt of male from the same treatment. Fertilizing solution (4 $\mathrm{g}$ of sodium chloride and $3 \mathrm{~g}$ urea/L water) was continuously added to improve the fertilizing rate (Horváth et al., 2002). Within two to three minutes after fertilization, eggs were evenly spread into 4-L plastic bowl containing $2 \mathrm{~L}$ clean water for incubation. The incubators were receiving fresh well aerated water at temperature of $25 \pm 1^{\circ} \mathrm{C}$ and water flow rate in each incubator was adjusted so that the fertilized eggs rotate gently. Dead eggs were siphoned off several times to keep all jars clean and for disinfection of eggs. Eggs fertilization was microscopically determined after putting them into Karpachenkov solution three hours after fertilization (Zonneveld, 1984). The Karpachenkov solution consists of two solutions A and B, which were mixed in equal parts just before eggs fixation. Solution A was made of $100 \mathrm{ml}$ acetic acid $+85 \mathrm{ml}$ distilled water $+10 \mathrm{~g}$ chromtrioxide. Solution B consisted of 300 $\mathrm{ml}$ formalin $(40 \%$ formaldhyde $)+550 \mathrm{ml}$ distilled water. The Karpachenkov solution was used as fixative for eggs coloration. Fertilization success was determined by observing 100 eggs from each fish under a microscope, when eggs were at the gastrulation stage. 


\section{The morphometric measurements}

The morphometric measurements were carried out for each fish at the laboratory; weight of fish $(\mathrm{g})$, total length $(\mathrm{cm})$, weight of gonad $(\mathrm{g})$ and stages of sexual maturation.

Gonado-somatic index (GSI) = 100 [ovary weight (g)/body weight (g)] (Zonnevld et al., 1988);

Fulton's condition factor $\left(\mathrm{K}_{\mathrm{f}}\right)=\left(\mathrm{W} / \mathrm{L}^{3}\right) \times 100$

Hastings and Dickie (1972);

Where, $\mathrm{W}$ is the body weight in $\mathrm{g}$ and $\mathrm{L}$ the total length in $\mathrm{cm}$.

Absolute fecundity $(\mathrm{AF})=($ Gonad weight $\times$ number of eggs in sub sample) / sub sample weight (Yelden and Avsar, 2000);

The relative fecundity $(\mathrm{RF})=$ the number of eggs (AF) / g (Nikolosky (1963);

Egg diameter: Oocyte diameter frequency helps to know the spawning season, for each female, the diameter of at least 10 of the largest oocytes were measured using a binuclear. Oocyte were separated from the ovarian tissue and put in formalin; $4 \%$ then, they were taken on a slide. Oocyte diameter was determined by using an eye-piece micrometer in the binuclear at a power magnification of $10 \mathrm{X}$ and then the measurement were converted into $\mathrm{mm}$.

Stages of oocyte maturation (Egg development): The stages of oocyte maturation was determined from oocyte samples fixed in clearing fixative (6:3:1, ethanol 95\%: formole 40\%: glacial acetic acid) according to Prat et al. (2001). Oocytes were classified according to Zanuy et al. (1986) into one of four groups, depending on the position of the germinal vesicle $(\mathrm{GV})$ : oocyte prior final maturation in which GV occupies a central position (CGV), oocyte with migrating GV (MGV), oocytes in which GV has migrated to a peripheral position (PGV), and oocyte which have completed germinal vesicle breakdown and in which the yolk has become transparent (GVBD).

Ovulation index $(\mathrm{OI})=$ weight of stripped egg mass / (weight of stripped egg mass + remnant ovaries) $\times 100$ (Szabo et al., 2002);

\section{Fertilization rate:}

Fertilization rate $(F R)=($ Number of fertilized eggs / Total number of counted eggs) x 100 .

\section{Steroid hormones analysis:}

Plasma levels of estradiol-17 $\beta\left(\mathrm{E}_{2}\right)$ were measured by Enzyme radioimmunoassay (ERIA) using the method described by (Rajkowski et al., 1977). The inter- and intra-assay variation was 3.2 and $5.4 \%$ for $E_{2}$. Females of African catfish were used for each month during one year to determine the steroid analysis estradiol $\left(E_{2}\right)$. Blood samples were taken from the heart by using heparinized disposable syringes and the plasma was separated by centrifugation at $3000 \mathrm{rpm}$ for $10 \mathrm{~min}$ and stored at $-20^{\circ} \mathrm{C}$ until further steroid analysis.

\section{Statistical analysis:}

The obtained data were subjected to one way ANOVA and differences between means were tested at the $5 \%$ probability level using Duncan's test. All the statistical analysis were done usin.SPSS program V 10
(SPSS, Richmond, USA) as described by Dytham (1999).

\section{RESULTS}

\section{Seasonal reproductive biology of African catfish females.}

\section{Gonado- somatic index (GSI):}

The monthly fluctuations in GSI of females are represented graphically in Figure 1, which included the mean average GSI values calculated in different months. Average GSI attained the lowest value $(0.52 \%)$ in February, which increase during April, May, June, July and August, being 6.33, 11.37, 10.68, 9.63 and 9.31\%, respectively. The highest value of GSI was in May (11.37). GSI decreased in the period from September (6.42) to April $(6.337 \%)$. Statistical analysis showed that insignificant differences between the months from May to August. Also, there are insignificant differences between the months from October to March.

\section{Condition factor $\left(\mathbf{K}_{\mathrm{f}}\right)$ :}

The monthly changes of $\mathrm{Kf}$ of African catfish females are showed in Figure 1. Average $K_{f}$ attained the lowest value (0.56) in August. It started to increase significantly during October, November, December and January, being $0.76,0.78,0.70,0.79$ and 0.93 respectively, then it reached the highest value (0.93) in January. Statistical analysis showed that no significant differences between the months.

\section{Fecundity}

Absolute fecundity (AF):

Table 1 shows the monthly changes in absolute fecundity of African catfish females. Average AF attained the lowest value (300) in February. It started to increase significantly $(\mathrm{P}<0.05)$ during March, April, May and June, being $8.84 \times 10^{3}, 40.48 \times 10^{3}, 41.47 \times 10^{3}$ and $48.44 \times 10^{3}$ respectively. Then it reached the highest value $\left(53.99 \times 10^{3}\right)$ in July.AF decreased in period from December $\left(2.15 \times 10^{3}\right)$ to February $(0.3 \times$ $\left.10^{3}\right)$. There were no significant differences from April to August, which showed the highest values of AF while it was insignificantly different from September to March, which demonstrate the lowest values of AF.

\section{Relative fecundity (Rf)}

The monthly changes in relative fecundity (Rf) of African catfish females are showed in Table 1, Average Rf attained the lowest value (0.68) in February. It started to increase during March, April and May being 19.93, 59.07 and 89.79 respectively till it reached the highest value (149.11) in June. Rf was insignificantly affected by monthly variations from September to April.

\section{Egg diameter}

The measurements of ova diameter can give a knowledge about the time and duration of the spawning of a given fish species. The oocyte diameters for different months of $C$. gariepinus were presented in Table 1. Oocyte diameter was increased from March to September, then an average oocyte diameter decreased in October $0.72 \mathrm{~mm}$. Insignificant decrease in average egg diameter was clear in the period from November $(0.4 \mathrm{~mm})$ till February $(0.17 \mathrm{~mm})$. Statistical analysis 
revealed that there are some significant differences $(\mathrm{P}<0.05)$ among months.

\section{Maturity stages:}

Ovaries of African catfish females showed great changes of size during different months of the year, these changes were used to morphological definition of the different maturity stages. Four groups, depending on the position of the germinal vesicles $(\mathrm{GV})$; Oocyte prior final maturation in which GV occupies a central position (CGV), oocyte with migrating GV (MGV), oocytes in which $\mathrm{GV}$ has migrated to a peripheral position (PGV), and oocyte which have completed germinal vesicles breakdown and in which the yolk has become transparent (GVBD). The monthly variation in female sexual maturity of $C$. gariepinus was graphically represented in Figure 2. Immature ovaries started to appear in October $(40 \%)$, recorded the highest value in December, January and February $(60 \%)$. CGV ovaries started to appear in February (20\%), then increased in March (40\%). MGV ovaries in March (20\%), then increased in April (60\%), and recorded the highest value in May (100\%). PGV in April (40\%), then in June, July and August recorded the highest value (100\%). GVBD in September $(100 \%)$, then decreased in November and December (40\%).

\section{Esteradiol hormone $\left(\mathbf{E}_{2}\right)$ :}

Data are graphically represented in Figure 3. Average $\mathrm{E}_{2}$ attained the lowest value $(15.73 \mathrm{pg} / \mathrm{ml})$ in October. Then reached the highest values 2381.2, 2248.4 and $1386.22 \mathrm{pg} / \mathrm{ml}$ in April, May and June, respectively. Female $E_{2}$ decreased in period from September (72.56) to January $(147.02 \mathrm{pg} / \mathrm{ml})$. Esteradiol hormone was insignificantly affected by monthly variations in April, May and June.

\section{Gonado-somatic index (GSI).}

Gonado somatic index was insignificantly affected by different treatments of hormones (Table, 3). The group of catfish injected by $\left(0.5 \mathrm{ml} \mathrm{kg}^{-1}\right.$ ovaprim $)$ had the lowest GSI $12.82 \%$, while the group of catfish injected by ( $0.4 \mathrm{ml}$ ovaprim $\mathrm{kg}^{-1}$ fish) had the highest GSI (17.38\%).

\section{Fecundity}

Absolute fecundity (AF).

Effects of different hormones after 12 hours from injections on AF of African catfish female are presented in Table (2). There were significant differences $(\mathrm{P}<0.05)$ among group of catfish injected with different hormones. The group of catfish injected by 1000 IU

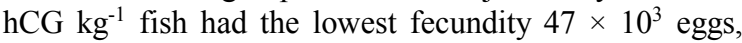
while the group of catfish injected by $0.4 \mathrm{ml}$ ovaprim $\mathrm{kg}^{-1}, 3000 \mathrm{IU}$ hCG $\mathrm{kg}^{-1}$ fish had a significantly highest fecundity $\left(105 \times 10^{3}\right.$ and $104 \times 10^{3}$ eggs $)$.

\section{Relative fecundity (RF)}

The group of catfish injected by $0.5 \mathrm{ml}$ ovaprim $\mathrm{kg}^{-1}$ had a significantly the lowest values of RF (96.46), while the group of catfish injected by $\left(1 \mathrm{ml} \mathrm{GnRHa} \mathrm{\textrm {kg } ^ { - 1 }}\right.$ fish) had a significantly highest RF (182.58) (Table 2). However, the significant differences of RF among the groups are not clear.

\section{Ovulation index}

The significant differences $(\mathrm{P}<0.05)$ among treatments were observed. However, ovulation index was insignificantly different in all treatments compared to the control group (Table 2), where Eggs could not be released from the ovaries of fish injected with saline solution.

\section{Egg diameter}

Effects of different hormones after 12 hours from injection on egg diameter of African catfish female are presented in Table 2. There were significant differences $(\mathrm{P}<0.05)$ among group of catfish injected by different hormones. The group of catfish injected by $0.4 \mathrm{ml}$ ovaprim $\mathrm{kg}^{-1}$ fish had the highest egg diameter (1.44 $\mathrm{mm}$ ), while, the fish group injected by $1000 \mathrm{IU}$ hCG $\mathrm{kg}^{-1}$ fish had the lowest egg diameter $(1.20 \mathrm{~mm})$.

\section{Fertilization rate (\%)}

Effects of different hormones at 12 hours after injections on fertilization rate of African catfish female are presented in Table (2). The fertilization rate in the control group was zero where no ovulation or fertilization happened in this group. The fish group injected by $0.5 \mathrm{ml}$ ovaprim $\mathrm{kg}^{-1}$ had the highest fertilization rate $(95.50 \%)$.

\section{DISCUSSION}

\section{Seasonal reproductive biology of African catfish females:}

GSI reflects the physiological activity of gonads, where the increase is an indication of the beginning of the spawning season of the fish. In this study GSI in the females attained the lowest value in February then it reached the highest value in May.

The fluctuations confirmed that African catfish began to spawn in May and continued until August. The water temperature, photoperiod, and prey items may persuade the spawning season of fishes.

Similar observations were reported in African catfish by Bruton (1979), Sharaf (1992), and Yalçin et al. (2001) who found an activity in the fish ovaries during summer.

They attributed this activity to suitable conditions and a combination of physical, chemical and biological factors, such as changes in water level, chemistry, $\mathrm{pH}$, temperature, clarity and flow velocity, flooting of marginal plants, associated chemical changes, and access to suitable spawning sites, is responsible for triggering the spawning of catfish. These results are in agreement with Tharwaat (2000) who found that GSI of African catfish females reached the maximum value during May. In contrast, Silva Freitas et al. (2011) found that the females presented the highest GSI value in March, when studied the seasonal changes in the GSI in catfish Auchenipterichthys longimanus.

Concerning the males GSI recorded the lowest value in November, then it reached the highest value in May. These results are in agreement with Sharaf (1992) and Tharwaat (2000) who found that (GSI) of African catfish males reached to maximum values during May. In contrast, Silva Freitas et al. (2011) found that the males presented the highest GSI value in January, when 
studied the seasonal changes in GSI in catfish Auchenipterichthys longimanus. Otémé et al. (1996) found GSI fluctuated from 0.20 to $0.65 \%$, with high individual variations and no seasonal trend was observed in the mean monthly sperm production, when studied the monthly variations of GSI in male African clariid catfish Heterobranchus longifilis.

The values of GSI and condition factor $\left(\mathrm{K}_{\mathrm{f}}\right)$ help to define reproductive cycles and possible variation in the physiological condition of species during the course of its lifespan (Kreiner et al., 2001 and Braga, 2005). The inspection of the seasonal variation of $\mathrm{Kf}$ is also being used as a complementary parameter aiming to describe natural cycles in reproduction and feeding ecology (Braga, 1986; Lizama et al., 2000; Anene, 2005). Concerning $\mathrm{K}_{\mathrm{f}}$ for African catfish females attained the lowest value in August then it reached the highest value in January. In general, the seasonal cycle in the condition factor of the fish suggested a relationship with gonadal development. The relationship between the spawning season and the condition factor was more discreet; even so, it is possible to verify an inverse relationship between $\mathrm{Kf}$ and GSI was given. The highest mean value of $\mathrm{Kf}$ was recorded in July (0.018), when the females presented the lowest GSI value. These results also suggest that the reduction in $\mathrm{Kf}$ value reflects the energetic costs of the reproductive process for both males and females (Silva Freitas et al., (2011). Although both the GSI and Kf are applied for evaluation of the reproductive cycle in fish, values of $\mathrm{Kf}$ may also reflect any changes in the feeding ecology of individual specimens (Braga, 1986; Kreiner et al., 2001; Gomiero and Braga, 2003 and Anene, 2005). For both genders we observed that the changing pattern of $\mathrm{Kf}$ was inversely related to GSI, which may be related to investments of the body's reserves into gonadal development (Braga, 1986).

Average $\mathrm{K}_{\mathrm{f}}$ in males attained the lowest value in July and it increased slightly during August, September, October, November and December, respectively. Silva Freitas et al., (2011) found that $\mathrm{Kf}$ for males was the highest in the juveniles (0.017) in comparison with the adults (0.009) when studied the seasonal changes in the allometric $\mathrm{Kf}$ in catfish Auchenipterichthys longimanus.

Fecundity is an important item in studying the fish reproduction (Nikolosky, 1965). With regard to $\mathrm{AF}$, the present study attained the lowest AF value in February, then reached to the highest value in July. This can be attributed to intra-specific variations in fecundity and egg size may be also related to the time of spawning. For example, there were eggs of 0.7 and $1.46 \mathrm{~mm}$ in May (Yalçin et al., 2001). The variation in fecundity between the populations may result largely from selectively different environmental factors such as water temperature, feeding and food abundance and species differentiation (Alp et al., 2004). Ahyaudin (1993) studied the fecundity of $C$. macrocephalus, and found that, absolute and relative fecundity also decreased with declining water level, however, mean relative fecundity is relatively constant (17.6 -53.7 oocytes /g body weight) and not related to body size. Absolute fecundity ranged between 785 to 14066 oocytes per female, whereas relative fecundity is between 7.1 to 83.5 oocytes/g body weights, respectively. Tharwaat, (2000) found that fecundity of African catfish and its relationships with total length, total weight and age of fish are graphically represented. It appeared to be a linear relationship, and expressed mathematically by regression equations recently. Hossain et al. (2013) reported that the mean total fecundity was 6740 and ranged from 1860 (for the smallest mature female, 4.27 g) to 19680 eggs for Morari Aspidoparia morar (Cyprinidae) in the Jamuna River. Yalc sin $_{\text {et al., (2001) }}$ found that fecundity varied from 4,483 to 336,157 eggs per female. Some researchers reported number of the fecundity of bocourti catfish was $6,980-9563$ eggs $/ \mathrm{kg}$ BW (Uppakarat et al. 2010), 21,139 eggs $/ \mathrm{kg}$ BW (Ngoichansri et al. 2010). Yet, Sirikul and Prarom (1995) reported that spawner female bocourti catfish, which weight $5.2-12.2 \mathrm{~kg}$ have average fecundity about 157,040 egg.

Moreover, Rf attained the lowest value in February, then it reached the highest value in June, because it revealed with egg numbers. El-Greisy (2000) illustrated that $\mathrm{Af}$ and $\mathrm{Rf}$ on Diplodus sargus increased by increasing weight and length. Hossain et al. (2013) reported that Rf ranged from 190 to 1200 for the Morari A. morar (Cyprinidae) in Jamuna River. ALP et al. (2004) found that Rf for each kilogram of female fish was 8434 eggs and each gram of ovary consists of 195 eggs prior to the spawning season of a native European catfish (Silurus glanis), where GSI confirmed that fish has a prolonged spawning period extending from the beginning of June to August.

Egg diameter reaching the maximum mean value in June, then average oocyte diameter decreased in October. A decrease in average egg diameter was clear in the period from November $(0.4 \mathrm{~mm})$ till February $(0.17 \mathrm{~mm})$. It has been already recorded in many previous studies that the presence of two or more modes of ova diameters in the ovary shortly before the spawning season indicates the long spawning season and the fractional spawning character as reported by Assem (1995), El-Greisy, (2000) and El-Ghamdy (2001). Yalcin et al. (2001) found that the egg diameter in African catfish was ranged between 0.2 and 1.54 from February to July. These results are in agreement with Tharwaat (2000) who found that the mean values of egg-diameter for African catfish were 0.36 and 0.45 $\mathrm{mm}$ in January and February, respectively. Also, an abrupt increase was observed during the period from March-May to reach its maximum value of $1.2 \mathrm{~mm}$ in May. These observations agrees with Sharaf (1992), Yalcsin et al. (2001) and ALP et al. (2004).

The monthly variation in female sexual maturity were immature ovaries during December $(60 \%)$ and the highest value was recorded in January $(60 \%)$. CGV ovaries started to appear in February $(20 \%)$, then increased in March (40\%), reaching the maximum in March (40\%). MGV ovaries in March (20\%), then increased in April (40\%), and recorded the highest value in May (100\%). PGV in April (40\%), then increased in June $(100 \%)$, and recorded the highest value in July (100\%). GVBD in September (100\%), then decreased in November $(40 \%)$. In the present study, however, 
seasonal fluctuations in maturity stages and the assumed GSI indicated that spawning took place from June to August, because the GSI value of African catfish caught in May was higher than that of the other months. These results are in harmony with Sharaf (1992).

Average $E_{2}$ attained the lowest value in October and it started to increase slightly during April, May and June. Then it reached the highest value in April. Female $E_{2}$ decreased in period from September to January. $E_{2}$, the major hormone of female fishes, is produced by the follicular layer of the developing oocyte by the conversion of $T$ to $E_{2}$ in an inner granulosa layer. The role of $E_{2}$ is to stimulate the liver to produce the yolk precursor protein, vitellogenin, which is then incorporated into the developing oocyte (Kime, 1993).

Changes in reproductive biology of African catfish females due to hormonal stimulation:

The second experiment used three hormones $(0.4$, $0.5 \mathrm{ml}$ ovaprim $\mathrm{kg}^{-1}$ fish, $1000,3000 \mathrm{IU}$ hCG kg-1 and $0.75,1 \mathrm{ml} \mathrm{GnRHa} \mathrm{kg}^{-1}$ ) to stimulate African catfish. GSI for the fish group injected by $0.5 \mathrm{ml}$ ovaprim $\mathrm{kg}^{-1}$ had the lowest GSI $(12.82 \%)$, while the fish group injected by $0.4 \mathrm{ml}$ ovaprim $\mathrm{kg}^{-1}$ had the highest GSI $(17.38 \%)$. These results are similar to that described with Sharaf (2005) who found that GSI was 12.92 and $12.74 \%$ after 6 and $12 \mathrm{~h}$ respectively when injected females of African catfish by $42 \mu \mathrm{g}$ GnRHs kg-1, while GSI was 10.69 and 11.39 after 6 and $12 \mathrm{~h}$, respectively after the injection of females African catfish with 200 IU hCG kg-1.

Moreover, the fish group injected by $1000 \mathrm{IU}$ hCG $\mathrm{kg}^{-1}$ fish had the lowest Af $\left(47 \times 10^{3}\right)$, while, the fish group injected by $0.4 \mathrm{ml} \mathrm{kg}^{-1}$ ovaprim and 3000IU hCG $\mathrm{kg}^{-1}$ fish had the highest Af $\left(105 \times 10^{3}\right.$ and $\left.104 \times 10^{3}\right)$. The variation in Af between the fish populations may result largely from selectively, different environmental factors such as water temperature, feeding and food abundance and species differentiation (Alp et al., 2004). Sharaf (2005) found that fecundity was $94 \times 10^{3}, 79 \times$ $10^{3}$ after 6 and $12 \mathrm{~h}$ respectively when injected females of African catfish with $42 \mu \mathrm{g}$ GnRHs $\mathrm{kg}^{-1}$, while

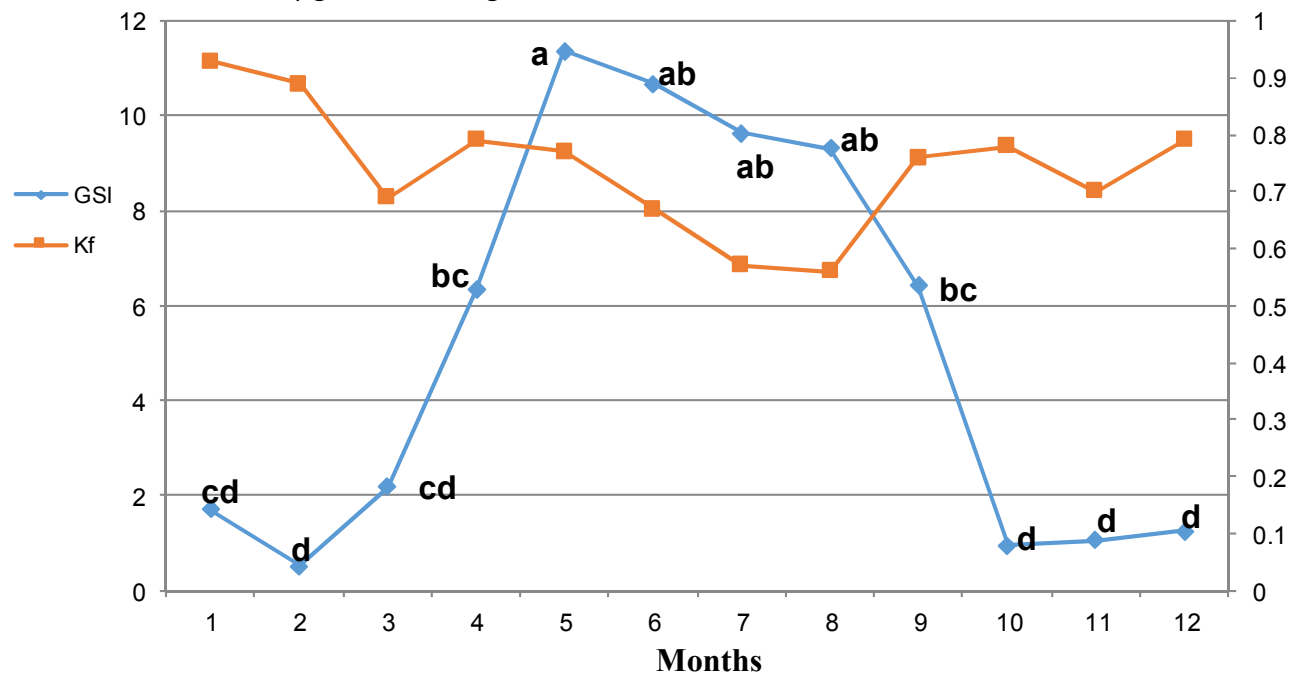

Figure 1: Monthly variations of the average gonado-somatic (GSI) index and condition factor (Kf) of female African catfish. fecundity was $65 \times 10^{3}, 56 \times 10^{3}$ after 6 and $12 \mathrm{~h}$ respectively, when injected females of African catfish with $200 \mathrm{IU} \mathrm{hCG} \mathrm{kg}{ }^{-1}$. In the fish group injected by 0.5 mlovaprim $\mathrm{kg}^{-1}$ had the lowest relative fecundity 96.46 , while the fish group injected by $1 \mathrm{ml} \mathrm{GnRHa} \mathrm{^{-1 }}$ fish had the highest Rf (182.58).

Ovulation index in the control fish group had the lowest ovulation index, while, the fish group of catfish injected by $1000 \mathrm{IU}$ hCG kg-1 fish had the highest ovulation index $(70.25 \%)$. The failure of fish to ovulate after treatment with saline solution may suggest that plasma gonadotropin $(\mathrm{GtH})$ levels in those fish had remained low. A surge in GtH can initiate final events of oocyte maturation and ovulation in African catfish (Richter et al., 1987). Sharaf (2012) found that ovulation index $(62.1,66.8$, and $73.1 \%$ ) in African catfish females injected by 20 and $40 \mu \mathrm{g} \mathrm{kg}^{-1} \mathrm{GnRHa}$ and $0.5 \mathrm{ml}$ ovaprim $\mathrm{kg}^{-1}$, respectively. Akar et al. (2010) found that ovulation was $90 \%$ for common carp females injected with hCG (first dose $1000 \mathrm{IU} \mathrm{kg}^{-1}$ fish and second dose $1000 \mathrm{IU} \mathrm{kg}{ }^{-1}$ fish). Sahoo et al. (2008) found that the injection of $3000-4000$ IU hCG $\mathrm{kg}^{-1}$ female weight in combination with 14-23 h latency period was suitable to get good stripping response for the highest weight of stripped egg in C. batrachus during induced spawning operation. Wang et al. (2010) found that higher values of the ovulation index at the combination of GnRHa and domperidone at doses $40 \mu \mathrm{g}$ $+20 \mathrm{mg} \mathrm{kg}{ }^{-1}$ body weight in yellow catfish (Pelteobagrus fulvidraco).

Egg diameter in the fish group injected by $0.75 \mathrm{ml}$ GnRHa $\mathrm{kg}^{-1}$ fish had the highest egg diameter (1.36 $\mathrm{mm}$ ), while, the fish group injected by $1000 \mathrm{IU}$ hCG $\mathrm{kg}^{-}$ ${ }^{1}$ fish had a significant lowest egg diameter $(1.20 \mathrm{~mm})$. Sharaf (2005) found that oocyte diameter was $1.19 \mathrm{~mm}$ after $6 \mathrm{~h}$ and $1.23 \mathrm{~mm}$ after $12 \mathrm{~h}$ when African catfish females were injected by $42 \mu \mathrm{g}$ GnRHs $\mathrm{kg}^{-1}$ ), while oocyte diameter was $1.16 \mathrm{~mm}$ after $6 \mathrm{~h}$ and $1.26 \mathrm{~mm}$ after $12 \mathrm{~h}$ when African catfish females were injected by $200 \mathrm{IU} \mathrm{hCG} \mathrm{kg}^{-1}$. 
Fertilization rate in the control fish group had the lowest fertilization rate, while the fish group injected by $0.5 \mathrm{ml}$ ovaprim $\mathrm{kg}^{-1}$ fish had the highest fertilization rate $(95.50 \%)$. The failure of the control fish to ovulate may suggest that plasma gonadotropin $(\mathrm{GtH})$ levels in those fish had remained low. A surge in GtH can initiate final events of oocyte maturation and ovulation in African catfish (Richter et al., 1987). In other fish, administration of ovaprim resulted in higher GtH levels than the control group, but the ability to cause oocyte maturation and ovulation depended on the dose, species (De leeuw et al., 1987; Ngamvongchon et al., 1988 and Peter et al., 1988). These results are similar to Sharaf (2012) who found that fertilization rate $(77.3,79.3$ and $84.0 \%$ ) in African catfish females injected by 20 and 40 $\mu \mathrm{g}$ GnRHa $\mathrm{kg}^{-1}$ and $0.5 \mathrm{ml}$ ovaprim $\mathrm{kg}^{-1}$ fish, respectively. Also, Brzuska (2003) found that fertilization rate was $84.14 \%$ when African catfish females were injected by $0.5 \mathrm{ml}$ ovaprim $\mathrm{kg}^{-1}$. Ragde (2000) and Dhabe Priyakumari (2002) reported that the fertilization rate and hatching percentage are generally higher with ovaprim as compared to pituitary extract.

Conclusively, the spawning season for African catfish is from April to September. However, $0.5 \mathrm{ml}$ ovaprim $\mathrm{kg}^{-1}$ fish has some advantages over hCG and GnRH treatments in terms of spawning index, higher fecundity and fertilization rate in African catfish females. Also, the best hormone and dose for males was (3000 IU hCG kg ${ }^{-1}$ fish. We can recommend that, the hormonal treatments could be a useful tool for commercial African catfish breeders to ensure high percentage of spawning.

Table (1): Monthly variations (mean $\pm \mathrm{SE}$ ) of absolute fecundity relative fecundity, and egg diameter of African catfish females $(n=5)$.

\begin{tabular}{|c|c|c|c|}
\hline Month & Absolute fecundity $\left(\times 10^{3}\right)$ & Relative fecundity $\left(\mathrm{x}^{2} 0^{2}\right)$ & Egg Diameter (mm) \\
\hline Jan & $3.17^{\mathrm{c}} \pm 2.36$ & $3.91^{\mathrm{e}} \pm 2.95$ & $0.46^{\mathrm{de}} \pm 0.28$ \\
\hline Feb & $0.30^{c} \pm 0.14$ & $0.68^{\mathrm{e}} \pm 0.33$ & $0.17^{\mathrm{e}} \pm 0.17$ \\
\hline Mar & $8.84^{\mathrm{c}} \pm 2.50$ & $19.93^{\mathrm{de}} \pm 4.41$ & $1.16^{\mathrm{ab}} \pm 0.11$ \\
\hline Apr & $40.48^{\mathrm{ab}} \pm 10.95$ & $59.07^{\text {cde }} \pm 10.65$ & $0.84^{\text {abcd }} \pm 0.09$ \\
\hline May & $41.47^{\mathrm{ab}} \pm 11.2$ & $89.79^{b c} \pm 26.12$ & $1.20^{\mathrm{ab}} \pm 0.04$ \\
\hline Jun & $48.44^{\mathrm{ab}} \pm 17.62$ & $149.11^{\mathrm{a}} \pm 50.81$ & $1.40^{\mathrm{a}} \pm 0.13$ \\
\hline Jul & $54.00^{\mathrm{a}} \pm 13.55$ & $119.44^{\mathrm{ab}} \pm 23.99$ & $1.12^{\mathrm{ab}} \pm 0.15$ \\
\hline Aug & $42.00^{\mathrm{ab}} \pm 7.68$ & $68.51^{\mathrm{bc}} \pm 11.25$ & $1.24^{\mathrm{ab}} \pm 0.06$ \\
\hline Sep & $25.23^{b c} \pm 10.51$ & $36.52^{\text {cde }} \pm 16.25$ & $1.08^{\mathrm{abc}} \pm 0.28$ \\
\hline Oct & $2.74^{\mathrm{c}} \pm 1.19$ & $4.69^{\mathrm{e}} \pm 1.99$ & $0.72^{\text {bcde }} \pm 0.30$ \\
\hline Nov & $2.73^{\mathrm{c}} \pm 1.84$ & $4.56^{\mathrm{e}} \pm 2.82$ & $0.40^{\mathrm{de}} \pm 0.24$ \\
\hline Dec & $2.15^{\mathrm{c}} \pm 1.05$ & $3.74^{\mathrm{e}} \pm 1.88$ & $0.50^{\text {cde }} \pm 0.21$ \\
\hline
\end{tabular}

Means in the same column having a different superscript letters are significantly different $(\mathrm{P}<0.05)$

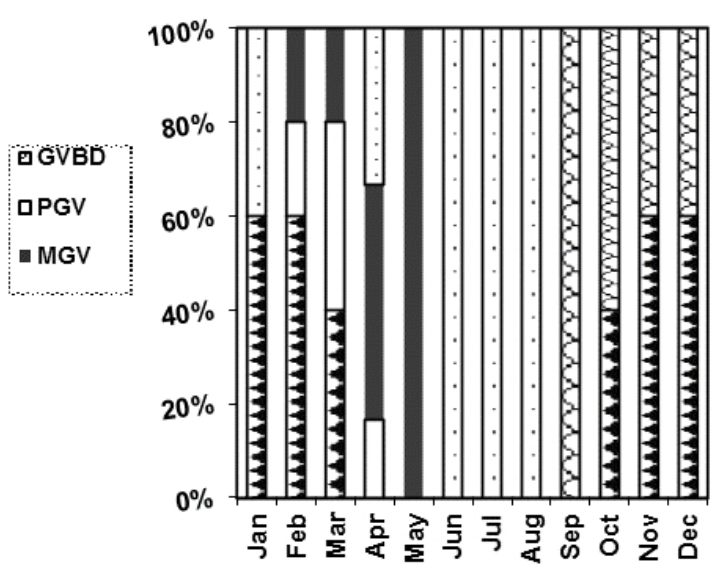

Figure (2): Monthly variations of oocyte maturity stages of African catfish females.

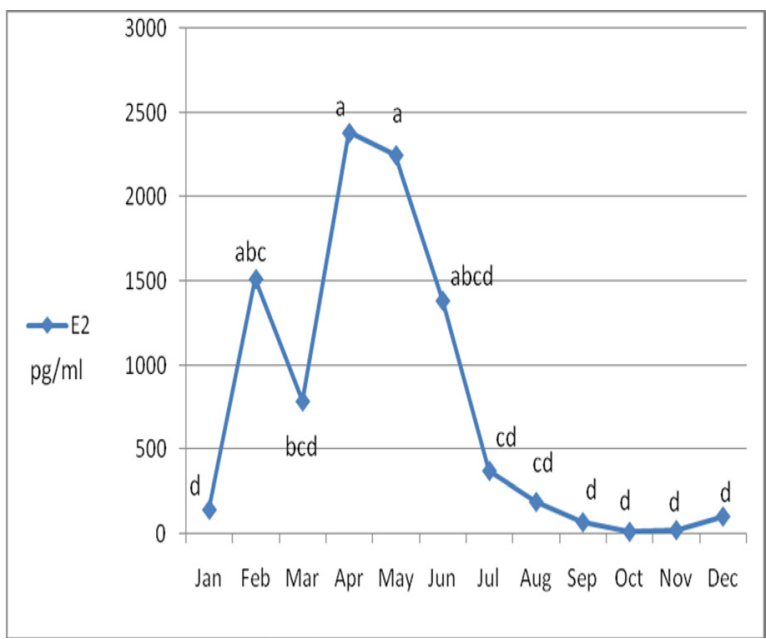

Figure (3): Monthly variations of esteradiol hormone $\left(E_{2}\right)$ of African catfish females.

Values with the same superscripts are not different significantly. 


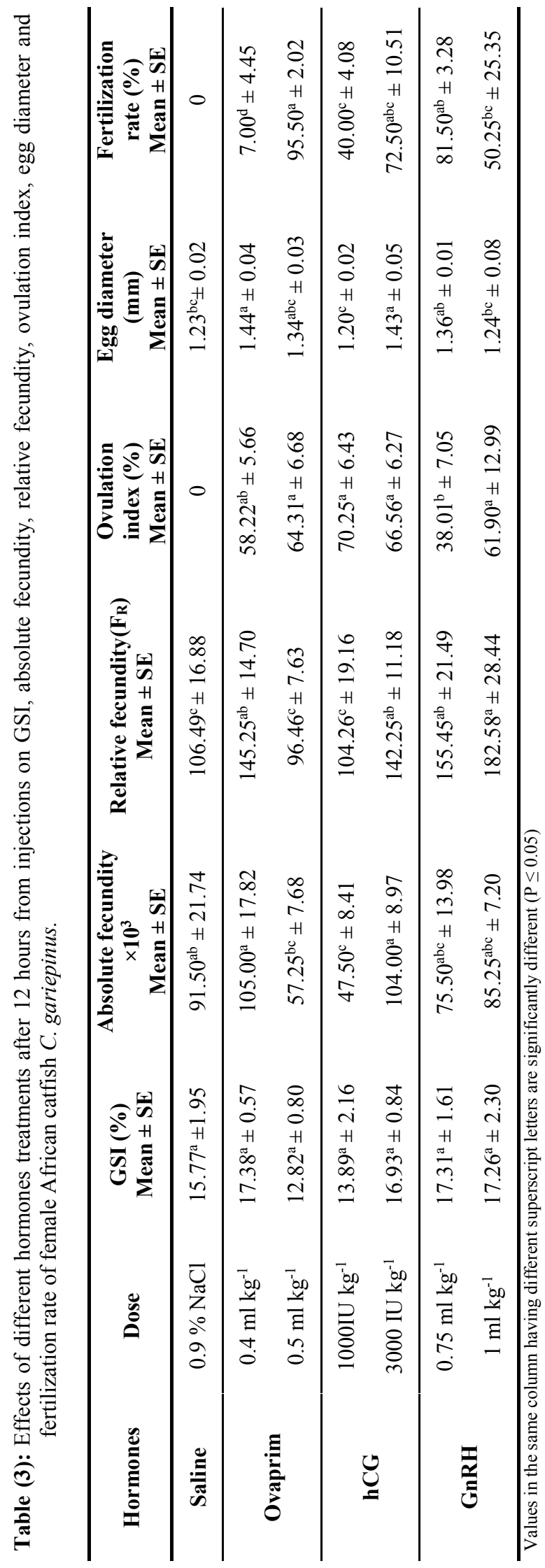




\section{REFERENCES}

Ahyaudin B. A. (1993). Aspects of the fecundity of the feral catfish, Clarias macrocephalus (Gunther), population obtained from the rice fields used for rice-fish farming, in Malaysia. Hydrobiologia, 254: 81-89.

Akar. A.M., Farag. M. E. and Ali, M. A. (2010). Comparative study showing the effect of injection with different doses of sex steroid hormones on reproductive performance of common carp (Cyprinus carpio L.) and grass carp (Ctenopharyngodon idella). Arabian aquaculture society. Vol. 5 No 1.

Ali, M.Z. and Jauncey, K. (2005). Approaches to optimising dietary protein to energy ratio for African catfish, Clarias gariepinus (Burchell, 1822). Aquacult. Nutr. 11: 95-101.

ALP, A., Kara, C. and Büyükçapar, H.M. (2004). Reproductive Biology in a Native European Catfish, Silurus glanis L., 1758, Population in Menzelet Reservoir. Turk J Vet Anim Sci. (28) 613-622.

Anene, A. (2005). Condition Factor of Four Cichlid Species of a Man-made Lake in Imo State, Southeastern Nigeria. Turkish Journal of Fisheries and Aquatic Sciences, 5: 43-47.

Assem, S. S. (1995): Reproductive biology and induced spawning of Solea species. Ph. D. Thesis, Faculty of Science, Alexandria University, Egypt.

Baranikova, I. A., Bayunova, L.V. and Semenkova, T.B. (2004). Serum levels of testosterone, 11ketotestosterone and oestradiol-17b in three species of sturgeon during gonadal development and final maturation induced by hormonal treatment. Journal of Fish Biology 64:1330-1338.

Barnhoorn, I.E.J., Bornman, M.S., Pieterse, G.M. and Van vuren, J.H.J. (2004). Histological evidence of intersex in Feral Sharptooth catfish (Clarias gariepinus) from an estrogens polluted water source in Gauteng, South Africa. Enviro. Toxicol., 19: 603-608.

Braga, F. M. S. (1986). Estudo entre fator de condição e relação pesocomprimento para alguns peixes marinhos. Revista Brasileira de Biologia, 46: 339346.

Braga, F. M. S. (2005). Feeding and condition factor of characidinn fish in Ribeirão Grande system, Southeastern Brazil. Acta Scientiarum Biological Sciences, 27: 271-276.

Bruton, M. N. (1979). The spawning biology and early development of Clarias gariepinus (Pisces: Clariidae) in Lake Sibaya, South Africa, with a review of spawning in species of the subgenus Clarias (Clarias), Trans. Zool. Soc. Lond. 35: 1-45.

Brzuska, E. (2003). Artificial propagation of African catfish (Clarias gariepinus): differences between reproduction effects after stimulation of ovulation with carp pituitary homogenate or GnRH-a and dopaminergic inhibitor. Czech J. Anim. Sci., 48 (5): 181-190.

Cejko B.I., Kowalski R.K., Kucharczyk D., Targoñska K., Krejszeff S., ־arski D., Glogowski J. (2009). Influence of the length of time after hormonal stimulation on selected parameters of milt of ide Leuciscus idus L. Aquacult. Res. 10.1111/j.13652109.

De leeuw, R., Goos, H. J. Th. and Van Oordt, P. G.W.J. (1987). The regulation of gonadotropin release by neurohormones and gonadal steroids in the African catfish, C. gariepinus. Aquaculture, 63: 43-58.

Dhabe Priyakumari, S. (2002). Comparative study on application of pituitary extract and ovaprim in Indian major carp Ph.D. Thesis Dr. Babasaheb Ambedkar Marathwada University, Aurangabad, India.

Dytham, C. (1999). Choosing and using Statistics: A Biologists Guide. Blackwell Science Ltd., London, UK. Pp 147.

El-Ghamdy, F.A. (2001). Reproductive biology, developmental stages and some biochemical characters of gonads for Aconthopagrus bifosciatus (Forskal, 1775) (Family: Sparidae), in Red Sea, Jaddah region, M. Sc. Thesis. Faculty of Science, Jaddah University, Soudia Arabia.

El-Greisy, Z. (2000): Reproductive biology and physiology of Diplodus sargus (Family: Sparidus) in the Mediterranean Environment. Ph. D. Thesis. Dep. Of Envir Alexandria Univ.., Egypt.

GAFRD, (2012). General Authority for fish resources development. Fish statistics year book. Ministry of Agriculture and land Reclamation Publications, Egypt, p. 106.

Gomiero, L. M. and Braga, F. M. S. (2003). Relação peso-comprimento e fator de condição para Cichla cf. ocellaris e Cichla monoculus (Perciformes, Cichlidae) no reservatório de Volta Grande, rio Grande- MG/SP. Acta Scientiarum Biological Sciences, 25: 79-86.

Hastings, W.H. and Dickie, L.M. (1972). Feed formulation and evalution. In: Halver, J.E. (ed.), fish nutrition, Acdemic press, London, 327-374.

Horváth, L., Tames, G. and Seagrave, C. (2002). Carp and pond fish culture, fishing News Books, $2^{\text {nd }}$ Edit., pp: 23-56

Hossain, M.Y., Arefin, M.S., Mohmud, M.S., Hossain, M. I., Jewel, M.A.S., M.M., Rahman, M.M., Ahamed, F., Ahmed, Z.F., and Ohtomi, J. (2013) : Length-weight relationships, condition factor, gonadosomatic index-based size at first sexual maturity, spawning season and fecundity of Aspidoparia morar (Cyprinidae) in the Jamuna River (Brahmaputra River distributary), Northern Bangladesh. Appl. Ichthyol. 1-4.

Kime, D. E. (1993). "Classical" and "non-classical" reproductive steroids in fish. Reviews in Fish Biology and Fisheries 3, 160-180. 
Kreiner, A., Van der Lingen, C.D. and Fréon, P. (2001). A comparison of condition factor and gonadosomatic index of sardine Sardinops sagax stocks in the Northern and Southern Benguela upwelling ecosystems, 1984-1999. African Journal of Marine Science, 23: 23-34.

Lizama, M. de los A. P. and Ambrósio. A. M. (2000). Condition factor in nine species of fish of the Characidae family in the upper Paraná River floodplain, Brazil. Brazilian Journal of Biology, 62: 113-124

May, R.C., G.S. Akiyama \& M.T. Santerre. (1979). Lunar spawning of the threadfin, Polydactylus sexfilis in Hawaii. U.S. Fish. Bull. 76: 900-904.

Mylonas, C.C., Fostier, A. and Zanuy, S. (2010). Broodstock management and hormonal manipulations of fish reproduction. Aquaculture, 165(3): 516-534.

Ngamvongchon, S., Pawaputanon, O., Leelapatra, W. and Johnson, W. E. (1988). Effectiveness of an LHRH analogue for induced spawning of carp and catfish in Northeast Thailand. Aquaculture, 74: 3540.

Ngoichansri, S., Rayan W. and Supsooksamran M. (2010). "Cage culture of Pangasius bocourti Sauvage, 1880 broodstock".Technical paper, Sakon Nakhon Inland fishery Research and Development Center, Department of Fisheries, Thailand, $19 \mathrm{pp}$.

Nikolosky, G. V. (1963). The Ecology of Fishes. Academic press, London and New York.

Nikolosky, G. V. (1965). Theory of fish population. Academy of science, U. S. S. R.

Otémé, Z.J., Nunez, R.J., Kouassi, C.K., Hem, S. and Agnese, J.F. (1996). Testicular structure, spermatogenesis and sperm cryopreservation in the African clariid catfish Heterobranchus longifilis (Valenciennes, 1840). Aquacult. Res., 27: 805813.

Peter, R. E., Lin, H. R. and Van Der Kraak, G. (1988). Induced ovulation and spawning of cultured freshwater fish in China: advances in application of GnRH analogues and dopamine antagonists. Aquaculture, 74: 1-10.

Prat, F., Zanuy, S. and Carrillo. M. (2001). Effect of gonadotropin realeasing hormone analogue (GnRHa) and pimozide on plasma levels of sex steroids and ovarian development in sea bass (Dicentrachus labrax). Aquaculture, 198: 325-338.

Ragde, V.R. (2000). An observation of gonadal axis in relation with spawning activity in Indian major carps Ph.D. Thesis, Marathwada University, Aurangabad, India.

Rajkowski, K. M., Cittanova, N., Desfosses, B. \& Joyle, M. P. (1977). The conjugation of testosterone with horse radish peroxidase and a sensitive enzyme immunoassay for the conjugate. Steroids 29(5), 701-713.

Richter, C.J.J., Viveen, W.J.A.R., Eding, E.H., Sukkel, M., Rothuis, A.J., Van hoof, M.F.P.M., Van Berg, F.G.J. and Van Oordt , P.G.W.J. (1987). The significance of photoperiodicity, Water temperature and an inherent endogenous rhythm for the production of viable eggs by the African catfish, C.gariepinus Kept in subtropical ponds in Israel and under Israel and Dutch hatchery conditions. Aquaculture, 63: 169-185.

Sahoo, S. K., Giri, S.S. and Sahu, A.K. (2004). Effect of stocking density on growth and survival of Clarias batrachus (Linn.) larvae and fry during hatchery rearing. Journal of Applied Ichthyology 20:302305.

Sahoo, S. K., Giri, S. S., Chandra, S. and Mohapatra, B. C. (2008). Evaluation of Spawning Performance of Asian Catfish Clarias batrachus at different dose of hCG and Latency Period Combinations. Turkish Journal of Fisheries and Aquatic Sciences, 8: 249251.

Sharaf, S.M. (1992). Utilization of Pitutary Gland in the induced spawning of Clarias lazera. MSc. Thesis, Faculty of Agriculture, Suez Canal University.

Sharaf, S.M. (2005). Effects of gonadotropin releasing hormone (GnRHs) and human chorionic gonadotropin (hCG) on ovarian development and plasma levels of sex steroids in African catfish (Clarias gariepinus). Egypt.J. of Appl. Sci., 20 (7).

Sharaf, S.M. (2012). Effects of GnRHa, pimozide and Ovaprim on ovulation and plasma sex steroid hormones in African catfish Clarias gariepinus. Theriogenology 77: 1709-1716.

Silva Freitas, T.M., Consolação Almeida, V.H., Assis Montag, L.F., Rocha, R.M. and Fontoura, N.F. (2011). Seasonal changes in the gonadosomatic index, allometric condition factor and sex ratio of an auchenipterid catfish from eastern Amazonia. Neotropical Ichthyology, 9(4): 839-847.

Sirikul, C. and Prarom, V. (1995). "Culture and nursing of bocourti catfish, Pangasius bocourti Sauvage, 1880 larva". Technical paper, Chiangrai Inland fishery Station, Department of Fisheries, Thailand 23.

Szabo, T., Medgyasszay, C. and Horvath, L. (2002). Ovulation induction in nase (Chondrosmoma nasus, Cyprinidae) using pituitary extract or $\mathrm{GnRH}$ analogue combined with domperidone. Aquaculture, 203: 389- 395. doi: 10.1016/S00448486(01)00635-4.

Tharwat, A. A. (2000): Reproduction of the African catfish Clarias gariepinus inhabiting the river Nile in Egypt. Bulletin of Faculty of Agriculture, University of Cairo, 51: (4) 411-430. 23.

Uppakarat N., Choncham A., Prarom W. and Sriboonruang A. (2010). "Rearing broodstrock of the Pangasius bocourti Sauvage, 1880 in concreted tank". Technical paper, Nan Inland fishery station, Department of Fisheries, Thailand 13: 14 .

Vazzoler, A. E. A. M. (1996). Biologia da reprodução de peixes teleósteos: teoria e pratica. Maringá, EDUEM, 169p.

Wang, Y., Hu, M., Cheung, S. G., Paul K. S. Shin, P. K. S., Limin Song, L and Wang, W. (2010). Induced ovulation of Yellow catfish (Pelteobagrus fulvidraco) using a combination of a gonadotropin 
releasing hormone analogue and domperidone. Aquaculture Research, 41: 1243-1249

Yalçin, S., Solak, K. and Akyurt, I. (2001). Certain reproductive characteristics of the African Catfish (Clarias gariepinus Burchell, 1822) living in the River Asi, Turkey. Turk. J. Zool. 25: 453-460.

Yelden, H. and Avsar, D (2000). A preliminary study on the reproduction of rabbit fish (Siganus rivulatus, Forsskal, 1775) in northeast Mediterranean. Turkish Journal of Zoology 24: 173 - 182.

Zanuy, S., Carillo, M. and Ruiz, F. (1986). Delayed gametogenesis and spawning of sea bass (Dicentrachus labrax L.) Kept under different photoperiod and temperature regimes. Fish Physiol. Biochem, 2: 53-63.

Zohar, Y. And Mylonas, C. C. (2001). Endocrine manipulations of spawning in cultured fish: from hormones to genes Aquaculture 197: 99-136.

Zonneveld, N. (1984). The spawning season and the relation between temperature and stripping time of grass carp (Ctenopharyngodon idella) in Egypt. Bamidgeh, 36 (1).

Zonneveld, N., Rustidja, W. J., Viveen A. R. and Maduna, W. (1988). Induced spawning and egg incubation of the Asian catfish, Clarias batrachus. Aquaculture, 74:41-47.

$$
\begin{aligned}
& \text { بيولوجيه التكاثز الموسميه والتفريخ الصناعى لاناث القرموط الافريقى بعد الحث الهرموني }
\end{aligned}
$$

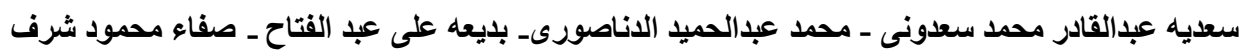

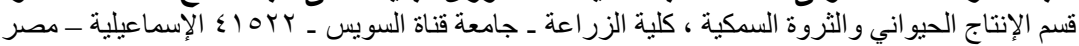

استخدام الهرمونات الخارجية فى الحث على اكمال مر احل النضج النهائى و التبويض و التفريخ اصبح من الخطوات الهات الهامة فى تكاثر

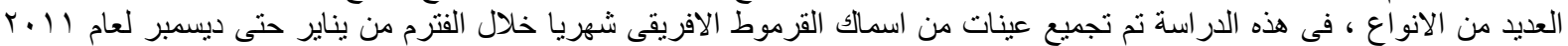

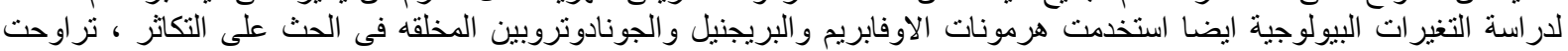

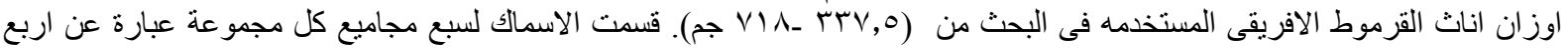

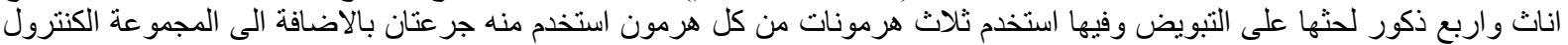

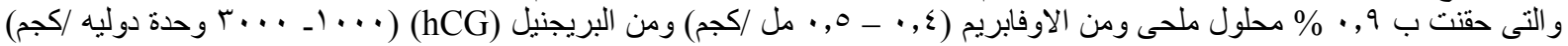

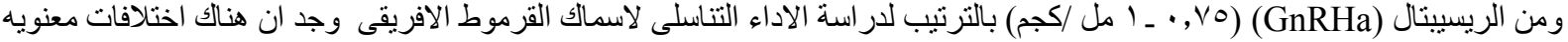

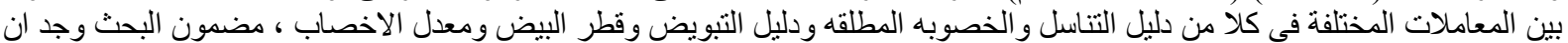

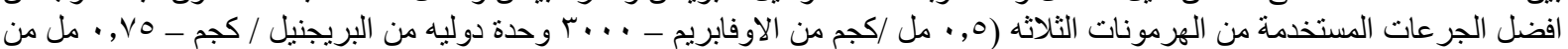

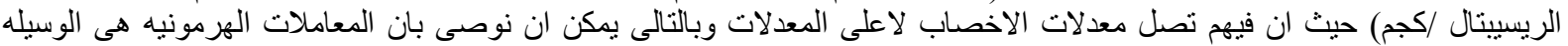

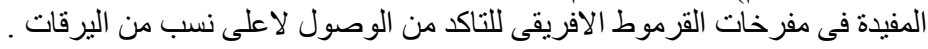

